\title{
Genesis of schlottenkarren on the Avon Peninsula of Nova Scotia (Canada) with implications for the geochronology of evaporite karsts and caves of Atlantic Canada
}

\author{
Max Moseley \\ P.O. Box 69, GPO, Pulau Pinang, 10700, Malaysia
}

\begin{abstract}
Exposed schlottenkarren karst terrains developed on gypsum-anhydrite evaporites in the Canadian Maritime provinces might be post-Glacial landscape features (formed on glaciallydenuded rocks after they are uncovered by progressive erosion of overlying glacial tills) or exhumed pre-Last Glacial Maximum (LGM) morphologies (filled with glacial till and revealed by erosion of the tills). In this paper the hydrological conditions necessary for the formation of schlottenkarren, the speleogenetic processes involved and their chronology are reconsidered and reinterpreted. It is proposed that they are essentially pre-LGM features which have survived from the Wisconsinan. It is concluded that the degree of glacial scouring and denudation of evaporite karsts in the region is highly variable and many or most karst landforms and associated caves probably have significant pre-LGM components in their development. Attention is drawn to the potential value of the chronological records in sediments preserved in these karsts for understanding the Quaternary in the region.
\end{abstract}

Keywords: $\quad$ schlottenkarren, gypsum, speleogenesis, geochronology, Canada

Received 27 October 2016; Revised 7 June 2017; Accepted 7 June 2017

Citation: Moseley M., 2017. Genesis of schlottenkarren on the Avon Peninsula of Nova Scotia (Canada) with implications for the geochronology of evaporite karsts and caves of Atlantic Canada. International Journal of Speleology, 46 (2), 267-276. Tampa, FL (USA) ISSN 0392-6672 https://doi.org/10.5038/1827-806X.46.2.2086

\section{INTRODUCTION}

Limestone, dolostone and evaporites, aptly termed 'the lithological trinity of soluble karst-forming rocks' by Friedman (1997), are all present in the eastern Canadian Maritime Province of Nova Scotia (Fig. 1). There is potential for karst terrains to form wherever any of these rocks are exposed, but outcrops of limestone and dolostone in the province are relatively restricted in area and it is the evaporite karsts developed on the Windsor Group gypsum-anhydrite beds which are the most widespread and intensively-developed (Moseley, 1996, Fig. 2). These Late Lower Carboniferous (Mississippian) strata underlie extensive areas on the Nova Scotia mainland and Cape Breton Island. Locally they can be several hundred meters in thickness. The largest areas of outcropping strata are in Halifax and Hants counties in central Nova Scotia and here they have been relatively lightly affected by Appalachian Orogen earth movements and often retain nearly horizontal bedding (Ford, 1997). In Cape Breton, Windsor Group bedrock is exposed mainly in the lowland areas to the west of the Bras D'or Lakes, although extensive areas are also believed to be submerged under the lakes as a result of rising post-Glacial sea-level (Baechler \& Boehner, 2014). Evaporite sequences and karsts are also present in the adjacent Maritime Province of New Brunswick (Moseley, 1996, Fig. 2).

Surface expressions of karstic geomorphology include doline fields, dry valleys, karren, sinks, springs and cave entrances. The most extreme morphological form is schlottenkarren. Very little work has been done on the genesis of this type of karst in Nova Scotia. In 2010 the discovery of Wisqoq Cave (Moseley et al., 2013) in an area of schlottenkarren on the Avon peninsula (Fig. 2) of Nova Scotia provided an opportunity to directly examine and describe the sub-surface morphological features of an example this type of karst development. Observations made here, supported by a reconsideration of the literature, make it possible to address unresolved questions about the chronology of schlottenkarren genesis and also to propose a plausible new model for the processes involved.

\section{DESCRIPTION OF THE KARSTS}

The surficial geology and karst terrains of Nova Scotia were shaped by the interaction of glacial and 
post-glacial as well as karstic and fluvial processes (Ford, 1997; Baechler \& Boehner, 2014). During the Quaternary the whole of the present-day area of the province was subjected to intensive continental glaciation. Marine isotope data from core samples of deep Atlantic Ocean sediments show that the region experienced at least sixteen glacial episodes, but in Nova Scotia only the last two glaciations, the Wisconsinan (c.75-11 ka before present) and the earlier Illinoian (c.190-128 ka), together with the intervening Sangamon Interglacial (c.128-75 ka) have been identified from stratigraphical evidence (Stea et al., 2011). Pre-Illinoian sediments and geomorphological features were presumably overridden and destroyed.

The Pleistocene glaciations profoundly changed the landscape of Nova Scotia and the gypsum karsts were

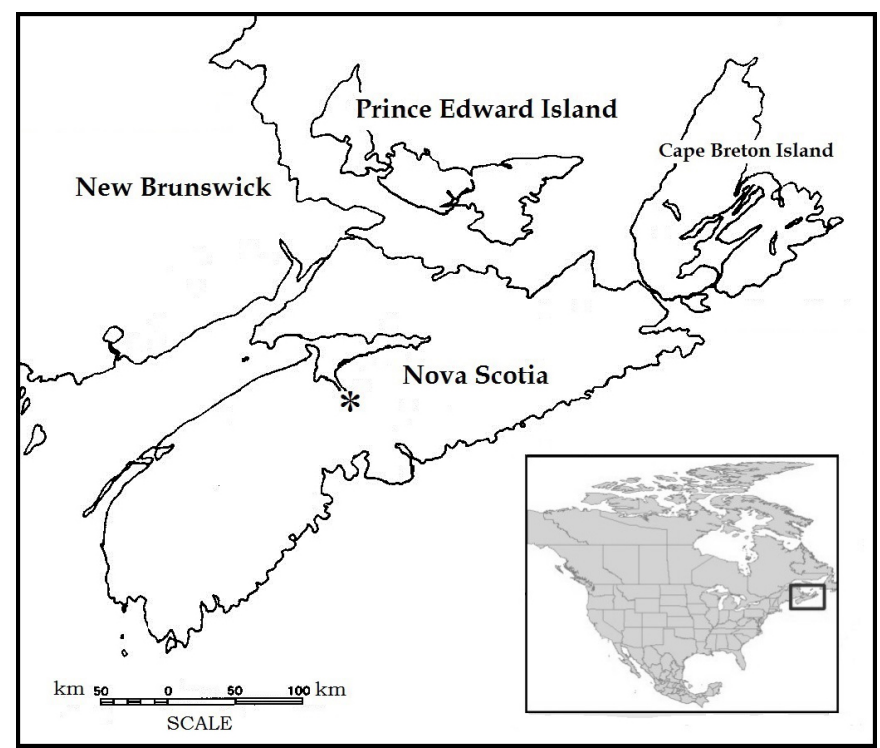

Fig. 1. Outline area map to show main geographical features of Maritime Canada. The asterisk shows approximate location of the Avon Peninsula. (Outline courtesy of d-maps.com at www.d-maps. com/carte.php?num car=4721\&lang=en). deeply affected. Many of the effects were destructive: karst surfaces were scoured and plucked; landforms modified or erased; and beneath the surface, caves and active conduits were chocked by glacigenic sediment and debris. However, a particularly important physiographic result of glaciation was that, following the final retreat of the ice sheets at the end of the Wisconsinan, most of the low-lying areas of the province remained blanketed by a thick cover of mostly impermeable unconsolidated ground moraine. In contrast to the destructive effects of glaciation this had a preservative effect on the karsts. Protected beneath surficial deposits the underlying bedrock remained shielded from direct dissolution by meteoric waters and it is only where the glacial till has been eroded away that the gypsum surface is exposed to direct weathering (Goodman, 1952; Ford 1987, Ford \& Williams, 1989; Moseley, 1996; Ford, 1997).

Most of the present-day gypsum karst landscapes of Nova Scotia are areas of low elevation with little topographical relief. For the most part the karst terrains are densely-forested areas of rugged nonarable land. Fields of suffosion and collapse dolines on glacial till are common. Areas of closely-spaced dolines resemble polygonal limestone karst ("eggbox karst"). The densities are up to 100 dolines / $\mathrm{km}^{2}$ and the largest individuals are $>500 \mathrm{~m}$ in diameter (Martinez \& Boehner, 1997). Individual dolines can reach depths up to $12 \mathrm{~m}$ or more (Goodman, 1952) and may be connected into underlying caves by channels leading from the bottom (Moseley, 1996). Many small active and inactive caves and cave fragments are documented in the province (Moseley, 1976; 1988a; 1988b; 1996; Ford, 1997) and more are being discovered. The longest gypsum caves known in the province are Arch Cave (Baddeck, Victoria County) and Hayes Cave (South Maitland, Hants County) which are respectively $520 \mathrm{~m}$ and $365 \mathrm{~m}$ in surveyed

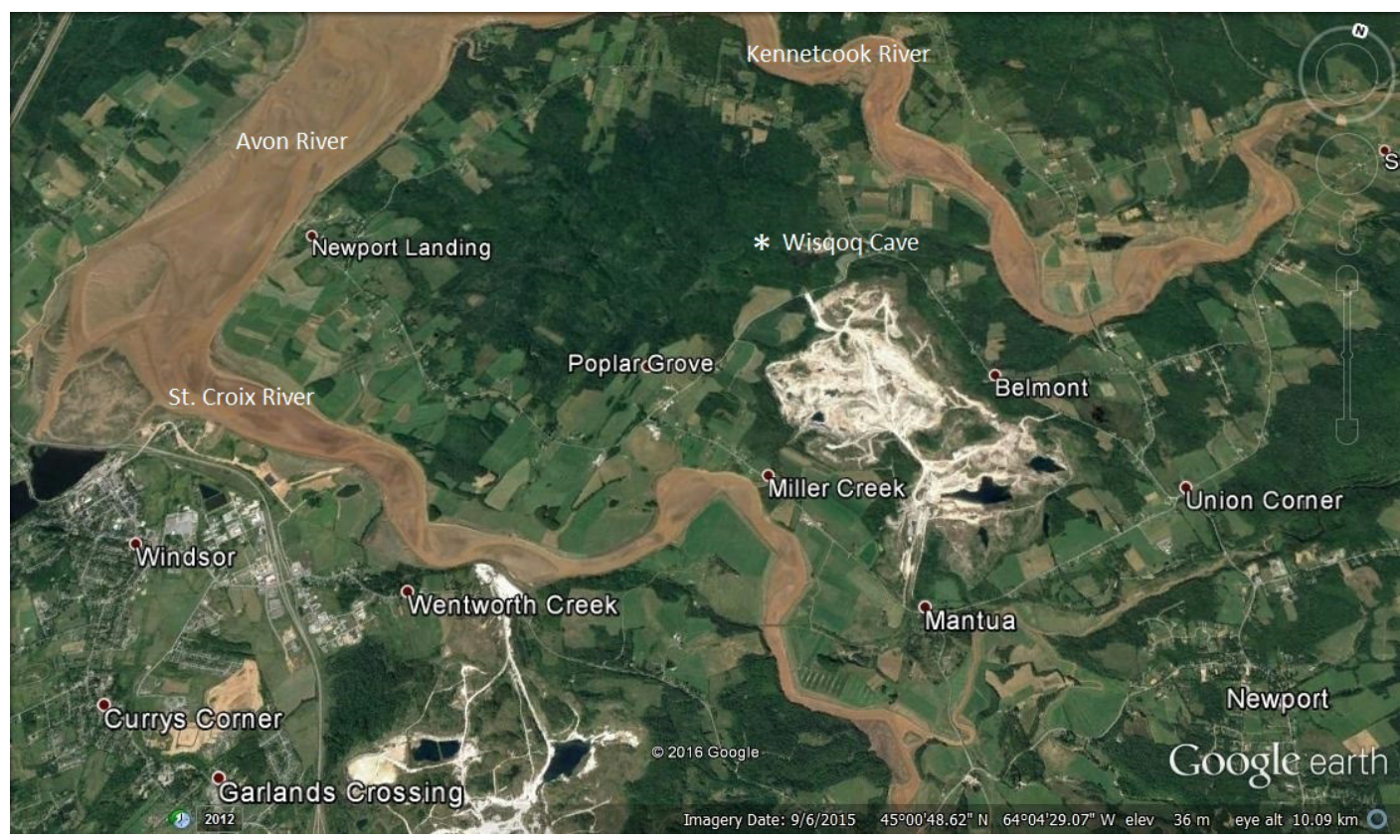

Fig. 2. Google Earth view of the Avon Peninsula, Hants County, Nova Scotia. The Kennetcook River and the St. Croix River drain westward into the Avon River. There are large tracts of unspoiled evaporite karst within the wooded land in the western interior of the peninsula. Extensive opencast workings clearly visible in the eastern part of the peninsula are those of the now inactive Millers Creek Quarry (Fundy Gypsum Company). Note that the marked position of Wisqoq Cave is approximate. [Google Imagery Date 9/6/2015 45॰00’48.62" N 64॰04' 29.07” W]. 
length. The existence of more extensive, integrated systems of active conduits is inferred from patterns of sinks and risings and other evidence (see below).

Widespread fields of dolines expressed on the surface of till-covered areas reveal the existence of hidden sub-surface karst. Although this buried karst, termed 'Deeply Till-Mantled Karst' by Ford (1997), is rarely accessible to direct investigation, stripping of overburden prior to blasting in the course of gypsum quarrying operations has provided temporary exposures of concealed underlying glacially-scoured karst surfaces, sediment-infilled sinkholes and other morphological palaeokarst features that survived (Stevenson, 1959, Plate IIIA; Moseley, 1996; Ford, 1997). The physical appearance of these uncovered surfaces suggested that glacial scour had only removed 1-2 $\mathrm{m}$ of rock, considered a surprisingly small amount for such soft rocks (Ford, 1997, p. 18). Other examples may be seen in cross-section in river, lake or sea cliffs (e.g., Moseley, 1996 p. 6). There is evidence that not all pre-last Glacial cavities were infilled: open shafts up to $12 \mathrm{~m}$ deep were reported to have been temporarily exposed in Fundy Gypsum Company's Millers Creek Quarry (Avon Peninsula, Hants County) (Moseley, 1996).

Areas where the overlying glacial till is eroded away exposing the bedrock were termed 'Bare/ thinly-mantled Evaporite Karst' by Ford (1997). Ford reported that this is typically found where there are steep physical or hydraulic gradients, for example river valleys and coastal or lakeside cliffs. Bare karst can however occur anywhere where there is sufficient gradient to permit erosion of surficial deposits.

The most extreme erosional form that develops on bare karst is 'schlotten karst' (Ford, 1987; Ford \& Williams, 1989), more accurately termed 'schlottenkarren' (Stenson, 1990; Ford, 1997). This form consists of groups of densely-packed dissolutional funnels draining into vertical cylindrical shafts typically with connections to subsurface cavities ('schlotten') beneath (Fig. 3). Morphometric analysis of examples in Canada (Stenson, 1990) revealed that at most sample sites mean rim diameters range from 0.5 to $1.5 \mathrm{~m}$, with little variance: means were larger $(1.8-3.5 \mathrm{~m})$ at the remaining sites. Mean nearest neighbour distances between sinkhole centres were between 1.0 and $3.5 \mathrm{~m}$. Most reported schlottenkarren are along river valleys or adjacent to coastal and lakeside cliffs (Ford, 1987, 1997; Moseley, 1996; Baechler, 2017, pers. comm.) but they also occur on bare karst elsewhere.

Datable organic remains are present in Quaternary palaeokarst infill sediments. Most appear to date from the Wisconsinan interstades. At Millers Creek Quarry a sample from under $20 \mathrm{~m}$ of glacial drift overlying the gypsum surface was dated at $33.2 \mathrm{ka}$ before present (Roland, 1982). At Milford Quarry, East Milford (Halifax County), wood at the base of a 12 m-thick till unit containing remains of beaver (Castor canadensis) yielded a radiocarbon date of $>33.8 \mathrm{ka}$ and tamarack (Larix) wood in organic deposits sandwiched between till filling karst depressions gave a date $>50.0 \mathrm{ka}$ (Harington, 1990, and references therein). Earlier

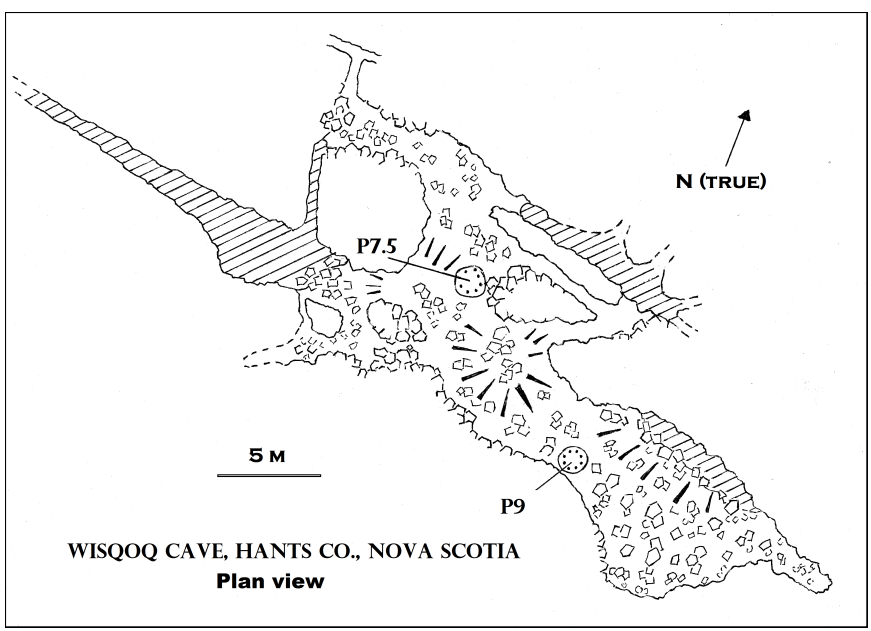

Fig. 3. BCRA Grade 3B map of Wisqoq Cave, Hants County, Nova Scotia [surveyed 2011 \& 2016]. P.7.5 and P.9 are the two entrance shafts.

deposits have also been identified. A partial American mastodon (Mammut americanum) skeleton and associated coprolites found in 1936 beneath till in a gypsum sinkhole in southern New Brunswick and formerly believed to be Middle Wisconsinan are now considered to be Sangamonian (Harington, 1990). Organic remains recovered during excavation of a fossilized stream sinkhole at Milford Gypsum Quarry in Halifax County (National Gypsum Company) include an American mastodon skeleton, frogs (Rana pipiens), turtles (Chrysemys picta and Clemmys insculpta) and pine cones, infilled during the Early Wisconsinan c. $75 \mathrm{ka}$ suggesting the fossil karst surface to date from the preceding Sangamon interglaciation. At this site the karst surface was buried by $c .30 \mathrm{~m}$ of glacial tills and interbedded sands (Grantham \& KozeraGillis, 1992; Holman \& Clouthier, 1995). Much earlier remnants survive in places: sedimentary fills with abundant Mesozoic plant remains and preserved in fissures on a karstified gypsum surface near Windsor (Hants County) are identified on palynological evidence as Lower Cretaceous (Falcon-Lang et al., 2007) whilst Baechler \& Boehner (2014, p. 708) report karst infills ranging from late Carboniferous through Cretaceous in Cape Breton.

Whilst the buried karst surfaces themselves are mostly hydrologically inert (Ford, 1997) the widespread coexistence around the province of gypsum, glacial deposits and sinkholes (Martinez \& Boehner, 1997); recent subsidence and the frequent opening up of new dolines (Hughes, 1957; Adams, 1991); and surface patterns of sinks and springs that reveal the existence of concealed integrated drainage systems (Moseley, 1996), prove active dissolution by groundwater within the gypsum strata beneath the till overburden.

The extent to which the schlottenkarren and other morphological features developed on exposed bare karst surfaces are post-glacial or, alternatively, represent earlier karstified surfaces disinterred by erosion of overlying till is unclear. Goodman (1952) recognised an association between distribution of the gypsum karst and glacial deposits, noting that the modern karst terrains are only present where there is no heavy cover of till. Hughes (1957) also observed that the surface expression of dissolution 
features depends on the thickness of the overlying glacial deposits. Hughes understood that there had probably been pre-Pleistocene karst development but concluded that rapid rates of dissolution evidenced by widespread instances of recent subsidence implied that exposed present-day solution features have developed since the last ice retreat. Moseley (1996) also surmised that the high solubility of gypsum in the natural environment (James et al., 1981; Klimchouk \& Aksem, 2005) points to a Holocene timescale.

Stevenson was the first geologist working in Nova Scotia to systematically observe and record karst in the course of geological mapping. The maps accompanying his Kennetcook and Shubenacadie report (Map Areas 1075A and 1076A) (Stevenson, 1959) were the first to consistently delineate observed areas of karst topography. A linear distribution alongside geographical features such as river valleys can be distinguished on these maps, though not explained or commented on in the text. It was not until nearly thirty years later that Ford (1987) recognised the significance of this. He observed that what he later (Ford, 1997) termed 'Bare/thinlymantled Evaporite Karst' is typically found where there are steep physical or hydraulic gradients, for example river valleys and coastal or lakeside cliffs. Moseley (1996) also commented that the then known vertical shafts are close to cliffs. In explanation of the observed distribution of these features Ford (1987, 1997, Fig. 2) and Ford and Williams (1989) proposed that Nova Scotia schlottenkarren are a result of progressive post-Glacial karstification of exposed surfaces where the overlying till has been eroded away. However Baechler and Boehner (2014 p. 711) pointed out that bare karsts on Cape Breton Island "may represent development of recent active karst systems and[or] reactivation of exhumed older karst erosion surfaces."

There has been almost no attempt to understand the speleogenesis of schlottenkarren in Nova Scotia. Moseley (1996) reported primitive phreatic protoconduits ("dip tubes") exposed in cross-section in a non-vertical joint at one site (The Honeycombs, see below). He suggested that, once primitive active conduits become large enough for there to be an airsurface (i.e., vadose flow), differential dissolution will tend towards the development of vertical shafts. Ford (1997) listed some essential requirements for the formation of evaporite schlottenkarren, and also pointed out the existence of outcrops of bare schlottenkarren in unglaciated regions, such as South Hartz of Germany, that are morphologically essentially the same as those in the glaciated karst of Nova Scotia (Kempe \& Emeis, 1979; Vladi, 1979; Ford, 1997). This implies that schlottenkarren do not display characteristics which necessitate involvement of glacial action in explanations of their creation.

\section{AVON PENINSULA}

The Avon peninsula, Hants County, Nova Scotia is geographically defined by three tidal rivers: the Kennetcook River to the north and the St. Croix River to the south, both of which drain westward into the Avon River (Fig. 2). Windsor Group gypsumanhydrite evaporites outcrop extensively on the peninsula. These easily-accessible deposits situated close to marine port facilities have been extensively exploited by one of the major producers, Fundy Gypsum Company. The eastern part of the peninsula has been heavily impacted by opencast quarrying operations (Fig. 2) during which the caves and other karst features formerly existing within the affected area were destroyed. In contrast, although there has been some historical small-scale mining, the elevated, wooded land in the interior of the western part of the peninsula remains for the most part intact and large tracts of unspoiled evaporite karst survive. This terrain is characterized by a series of low rolling hills (referred to locally as knobs or knolls), with moderately incised drainages and shallow valleys. There are extensive areas of bare karst terrain including outstanding examples of polygonal karst, schlottenkarren and associated caves.

A variety of cave morphological forms are described on the peninsula, most displaying morphologies indicating formation under shallow phreatic conditions. They include small joint-guided maze caves and a large truncated chamber apparently formed by mixing corrosion in the four component water-gypsum-calcite- $\mathrm{CO}_{2}$ system (Moseley, 1996 p. 10, 14, and Figs. 5, 9). Two caves, Wisqoq Cave and The Honeycombs, are interpreted as schlotten.

\section{WISQOQ CAVE AND THE HONEYCOMBS}

Wisqoq Cave, discovered in 2010 by a local resident, is situated in an area of schlottenkarren evaporite karst terrain (Fig. 4) in the western part of the Avon Peninsula (Fig. 2) (Moseley et al., 2013).

The cave (Figs. 3, 5) is entered through either of two vertical shafts, P9 (Fig. 6) and P7.5 (Figs. 7, 8) in deep dissolutional funnels on the top of a low karstified ridge. The topography of the land surface in the immediate neighbourhood shows two parallel low ridges separated by a shallow valley, all trending approximately east-west. The same primary structural elements almost certainly guided development both of surface and underground features. The known cave development is confined within one of the ridges and is oriented on a major joint or other structural discontinuity extending at $100^{\circ}-280^{\circ}$ along the axis of this ridge. Passage orientations suggest the presence of minor joints at c. $65^{\circ}-245^{\circ}$.

The shafts open into a large essentially formless low-ceilinged $(\leq 2 \mathrm{~m})$ horizontal cavern c. $20 \mathrm{~m}$ in length and up to $8 \mathrm{~m}$ wide, floored at a depth of c. 9-10 $\mathrm{m}$ below the present average land surface (Fig. 9). Shaft P9 narrows downwards and opens into the roof of the chamber. P7.5 is more regular in cross-section and is notable for well-developed 'flutes' (Fig. 8). A standing pond and staining on the walls indicate partial flooding of the chamber at some time (Fig. 9). Several blind cupolas in the ceiling of the chamber are evidence of former dissolution but there is no surviving evidence of a 'laugdecke' (the flat dissolutional roof typical of phreatic gypsum 


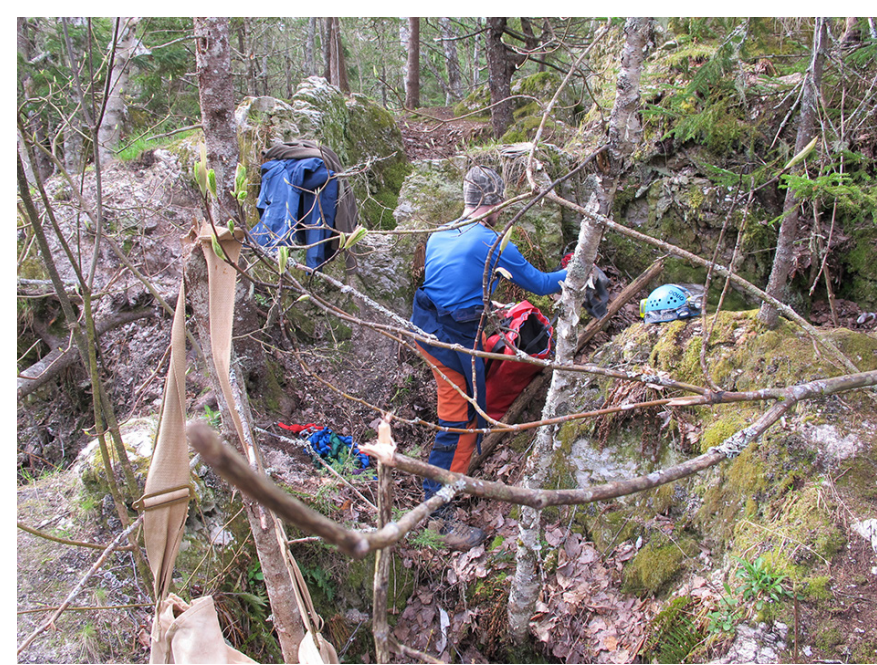

Fig. 4. Gypsum karst in vicinity of Shaft P.9, Wisqoq Cave. The shaft (illustrated in Fig. 6) is situated immediately beyond and hidden by the wall of gypsum behind the head of the caver (after Moseley et al., 2013).

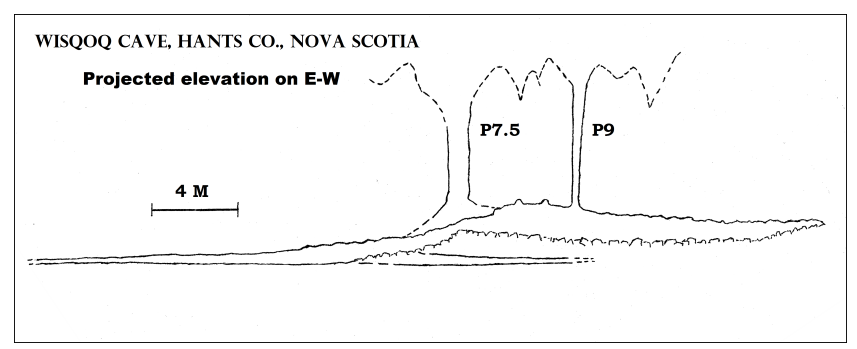

Fig. 5. Elevation sketch of Wisqoq Cave. Based on BCRA Grade 3B map (Fig. 3) but with all vertical profiles and depths estimated; surface profile conjectural.

caves e.g., Kempe et al., 1975; Moseley, 1996). The morphology of the chamber is a result of mechanical cavern breakdown (Fig. 9). However, to the north and west, low wet passages at what appears to be the local water-table indicate on-going dissolution at a level only c. $2 \mathrm{~m}$ below the chamber.

The Honeycombs (Fig. 10) and the adjacent Honeycombs II were dry abandoned caves situated in the eastern part of the peninsula. They were reported informally in a magazine article (Major, 1966) and described by Moseley $(1974,1996)$. The caves were located on a low ridge of gypsum immediately above the escarpment edge of the ridge. Adjacent marshy ground was interpreted as a drained post-Glacial lake bed. All of these features were destroyed in the early 1980 s in the course of quarrying operations.

The Honeycombs consisted of six almost perfect smooth-sided vertical shafts oriented in an approximately northwest-southeast line parallel to the escarpment. A separate similar shaft a few meters away from the main cave was probably connected to the main group via a constricted humanly-impenetrable passage. All the shafts were uniform in vertical profile apart from some widening due to weathering at the top. In cross-section they were elliptical with their long axis approximately northeast-southwest. The shafts did not show any relationship to dip of strata or fractures, but sets of small dip-tube-like features associated with a joint or fracture were exposed in cross-section in one shaft. The shafts expanded at the bottom creating small interconnecting chambers coalescing into a single passage formed mainly by mechanical collapse. Remnant multiple facettes

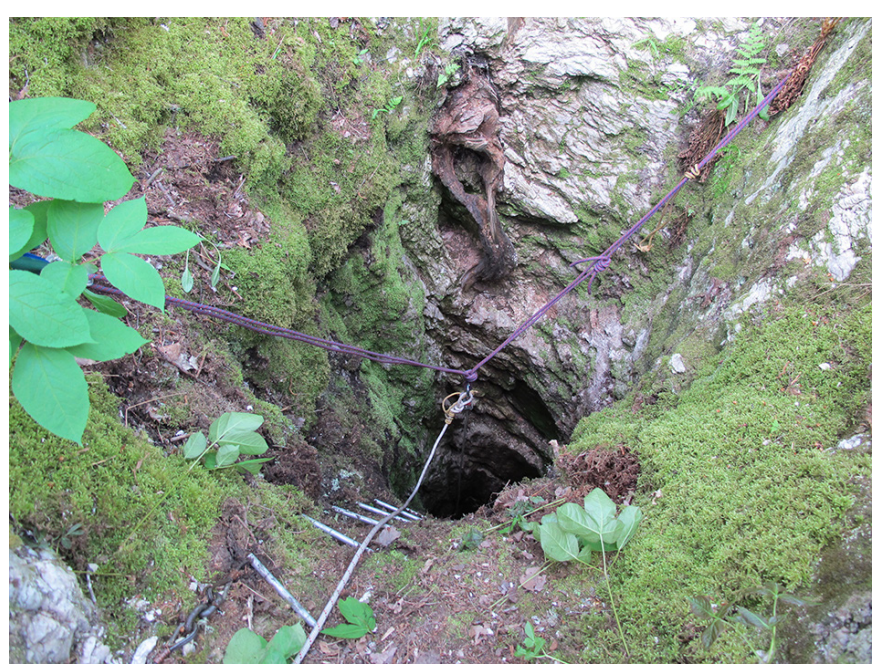

Fig. 6. Shaft P.9, Wisqoq Cave, from surface. The caving ladder indicates scale (photo: author).

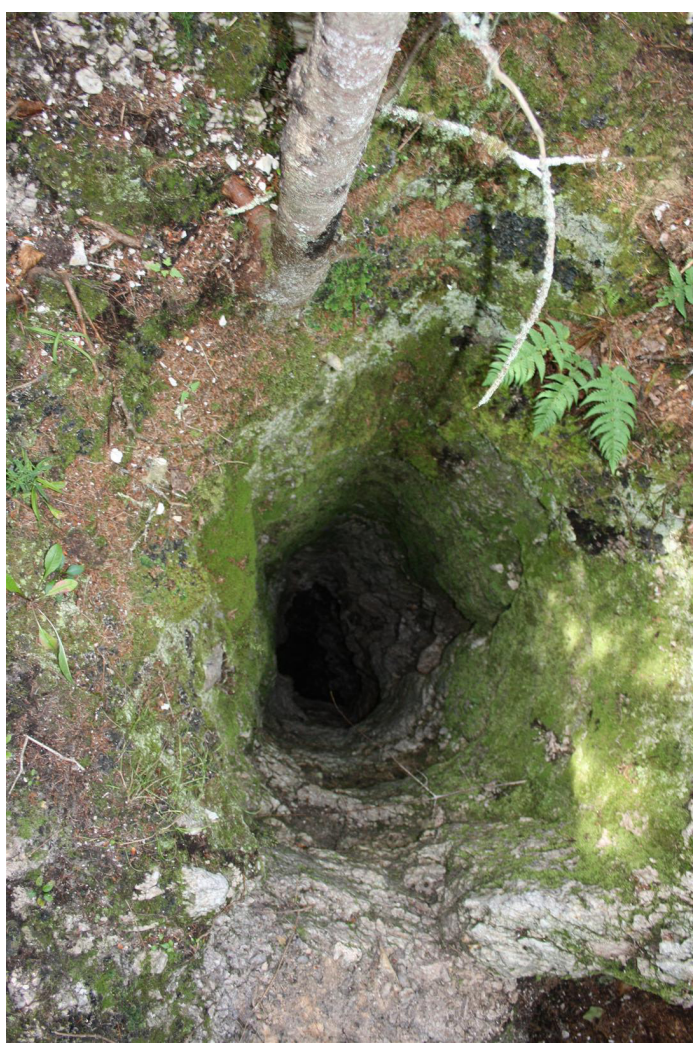

Fig. 7. Shaft P.7.5, Wisqoq Cave, from the surface. The scalloped cross-section visible lower down is due to the vertical fluting illustrated in Fig. 8 (photo: author).

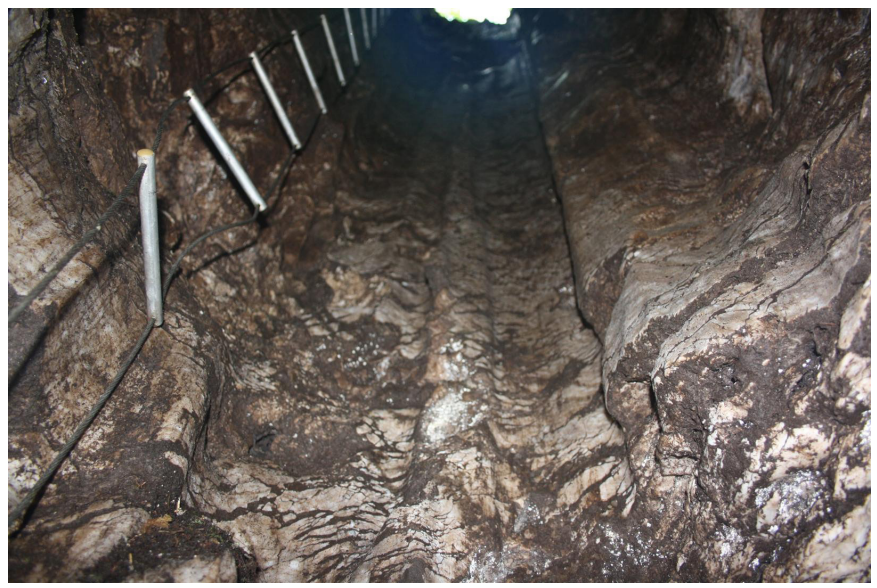

Fig. 8. Shaft P.7.5, Wisqoq Cave, looking up from underlying chamber, and showing the well-developed vadose fluting in this shaft. Caving ladder indicates scale (photo: Jonathan Guy). 
on the walls showed this to have originally been a phreatic laughöhlen passage, and a well-preserved laughöhlen passage extended beyond the area of the shafts (illustrated on p. 13-14 of Moseley, 1996). Facettes and laughöhlen (both described by Kempe et al., 1975) are typical morphologies of phreatic caves in gypsum.

The shafts were not situated within sinkholes and the gypsum surface in the vicinity was flattened and denuded by glacial scouring. A field of closely-spaced shallow depressions, believed to be further shafts or dissolutional funnels infilled by sediment and debris, extended some distance back from the escarpment.

\section{SPELEOGENESIS OF WISQOQ CAVE AND THE HONEYCOMBS}

There are substantial morphological resemblances between Wisqoq Cave and The Honeycombs and they are in the same general geographical locality. Both display speleogenetically distinct horizontal (phreatic) and vertical (vadose) morphological elements. The vertical elements consist of shafts opening into horizontal caves at a lower level, and appear to be fracture (joint?)-guided in origin. Analogous, and presumably contemporaneous, processes were undoubtedly responsible for the formation of both caves. However the modern gypsum surface in the vicinity of Wisqoq Cave (Fig. 6) is substantially less denuded than that formerly exposed at The Honeycombs.

Laughöhlen gypsum cave passage fragments in The Honeycombs displaying typical V-shaped crosssections and flat laugdecke ceilings (Fig. 10) were consistent with dissolution by slowly-moving water at or just below a local water-table (Gripp, 1912; Biese, 1931; Kempe, 1972; Pfeiffer \& Hahn, 1972; Kempe et al., 1975; Moseley, 1996, Fig. 3). It is evident that these elements of the cave developed at a past water table at the margin of an adjacent lake that previously existed here (Moseley, 1996). The cave became hydrologically inactive with the draining of the lake. In Wisqoq Cave, remnant phreatic features and the absence of any

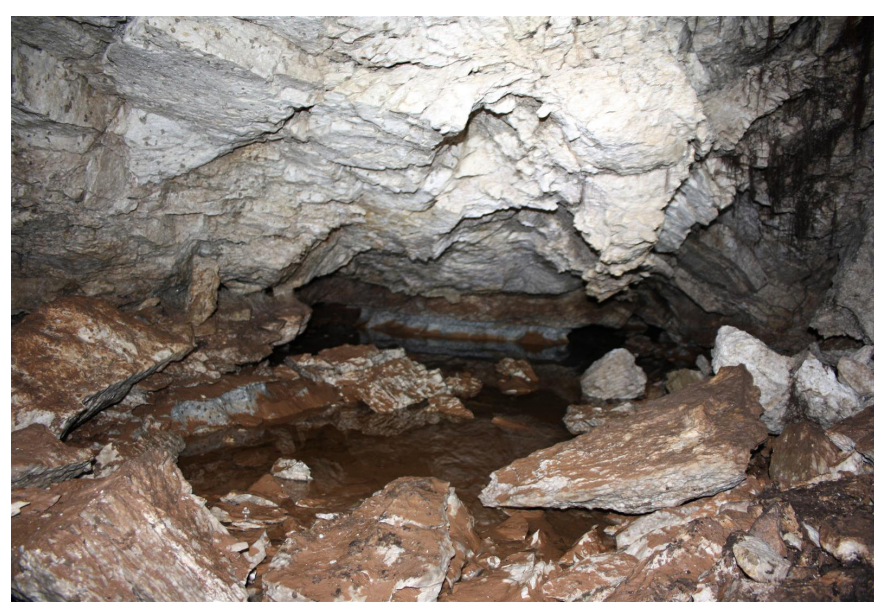

Fig. 9. Main chamber in Wisqoq Cave, from Shaft P.9 looking northeast. Gypsum blocks littering the floor together with the absence of dissolution surfaces on the ceiling show that the present-day chamber was formed by blockfall. Chocolate-coloured sediment on the rocks and 'tidemarks' visible on the far wall above the pool are evidence of intermittent changes in water-level (photo: author). evidence of vadose stream action in the chamber and lower passages show that these parts of this cave also originated under submerged phreatic conditions during a period when the local water table was higher than it is today. The Wisqoq Cave chamber, which is now drained, probably originated at the level of this water table, extensive cavern breakdown having resulted in upward propagation of the cavity.

Fluting and downwards narrowing of the shafts in Wisqoq Cave are diagnostic of development in the vadose zone, but the physical situation of both caves on gypsum ridges, together with the absence of any evidence of vadose action other than within the shafts themselves, rules out involvement of surface streams in their overall development. Alternatively, the verticality, depths up to nearly $10 \mathrm{~m}$, and cylindrical or near-cylindrical cross-sections of the shafts are consistent with schlottenkarren forms. Both caves are therefore interpreted as well-developed schlottenkarren morphologies draining into lower phreatic schlotten caves.

\section{A PLAUSIBLE MODEL FOR SCHLOTTENKARREN GENESIS}

Ford (1997, p. 14) listed some essential requirements for the formation of evaporite schlottenkarren as: exposure of rather pure bedrock, a high hydraulic gradient and sufficient precipitation. Whilst these are undoubtedly correct they are not in themselves sufficient to explain the morphological features of schlottenkarren. An acceptable genetic model has to explain the deep funnel-shaped surface morphologies, vertical vadose shafts, and underlying phreatic cavities. The model must also address the frequent (though not exclusive) close association of schlottenkarren with places such as cliff edges and the sides of river valleys, and be consistent with the existence of schlottenkarren in unglaciated regions (i.e., must not depend on any glacial or post-glacial process).

A model consistent with the above is that schlottenkarren develop as a result of the hydrological conditions at locations where (a) a sufficiently large hydraulic head above a water-table is combined

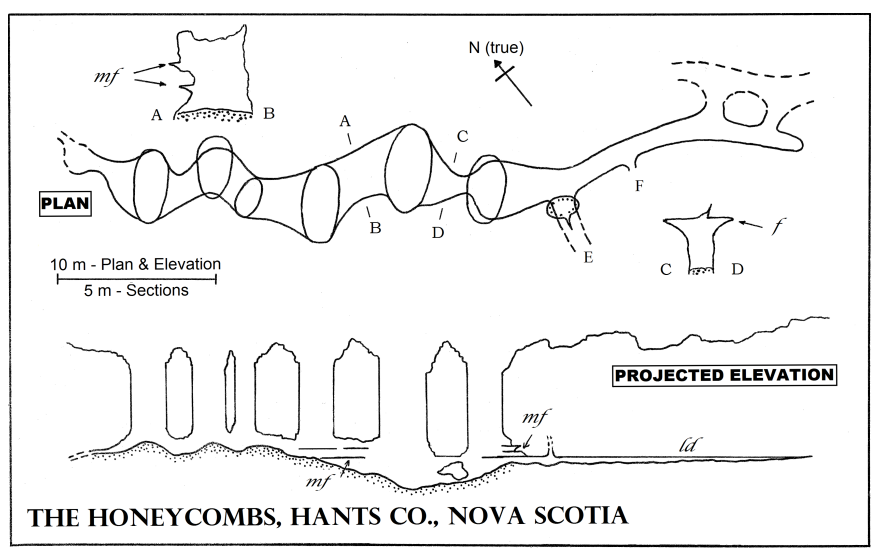

Fig. 10. The Honeycombs, plan and elevation based on Suunto and cloth tape survey (BCRA Grade 3B). KEY: $f=$ facette; $m f=$ multiple facettes; Id = laugdecken. Two impenetrable laughöhlen phreatic passages (marked $E$ and $F$ ) might have been outlets draining to an adjacent lake (After Moseley, 1996, modified). 
with (b) essentially unimpeded egress of water at a lower elevation. Where both these conditions are present, meteoric waters become freely-draining from the surface down to the water-table. Consequential focussed dissolutional expansion of primitive conduits within this vadose zone results in preferred conduits becoming large enough for there to be stream flow with free air-surfaces (vadose flow). Once stream flow is established, differential dissolution of the lower sides of the conduits results in development of vertical, relatively smooth-sided cylindrical or subcylindrical shafts.

The necessary free, unimpeded drainage into the phreatic zone from the bottom of the vadose shafts can only occur where there are underlying cavities of sufficient size to readily accept the flow, without backing up. Suitable physical and hydrological conditions exist along valleys and at river, sea and lakeside cliffs. Here, there is the potential for formation of underlying dissolutional cavities connected to and draining with little impediment into a nearby body of surface water, typically a river or lake. Here also, water flow from the surface will tend to be preferentially captured by those conduits closest to the external drain, which in consequence will develop faster than those further back. This explains the appearance of chronologically progressive development observed by Ford (1987). It follows that the commonly-observed relationship between sites subject to progressive erosion of overlying glacial tills and the presence of schlottenkarren is therefore not due to cause and effect: these processes are independent; both being results of the same hydrological conditions.

Where schlottenkarren occur in Nova Scotia, the maximum observed depth of the water-table below the top of the karst surface is c. $20 \mathrm{~m}$. It is not known if the processes involved in their genesis are physically limited by increasing depth of the water-table below the surface, but it may be very tentatively conjectured that restriction of water flow with increasing depth of the vadose zone might be a limiting factor.

\section{CHRONOLOGY}

A widespread view has been that present-day Nova Scotia gypsum karst surface morphologies and caves are essentially post-Glacial phenomena (Hughes, 1957; Ford, 1987; Ford \& Williams, 1989; Moseley, 1996; Ford, 1997). However, a review of the literature reveals that there is no reported physical geological evidence directly supporting a post-Glacial age. This chronology is based on assumptions that the intensity of glacial action on these soft rocks must have destroyed pre-existing karst surfaces, and that rapid rates of dissolution on exposed gypsum adequately explain the extent of karstification observed on exposed gypsum.

The alternative interpretation that at least some of exposed present-day karst terrains are exhumed preLGM erosion surfaces has been raised (Hughes, 1957; Baechler \& Boehner, 2014) but not investigated. This chronology offers a satisfactory explanation of the genesis of The Honeycombs, Wisqoq and other caves and is consistent with and reconciles the known geological evidence. Whilst it is difficult or impossible to envisage any post-Glacial process that might explain the unusual morphology of The Honeycombs, this cave is readily interpreted as the surviving remains, partly glacially-truncated, of schlottenkarren. Interpreted in this way, it constitutes strong evidence for survival of pre-LGM karst surfaces and caves. The model for schlottenkarren genesis, proposed above, does not invoke any Glacial or post-Glacial process and is consistent with a pre-LGM chronology.

There is ample evidence that pre-LGM gypsum karst surfaces have survived, buried beneath glacial deposits. Dated organic remains in stratified sediments infilling buried palaeokarst depressions are evidence that many such features have survived at least the Wisconsinan glaciations. Stratified sedimentary infills, for example at East Milford (Harington, 1990), show that these deposits are not a result of postglacial slumping. Reports by local quarrymen of open shafts temporarily exposed in the face of Millers Creek Quarry also support this view.

Evidence from a probable coeval site in the Codroy area in southern Newfoundland supports this conclusion. As in Nova Scotia, active gypsum karst in the area was initially interpreted (Sweet, 1978, p. 118) as "probably post-glacial" citing the fact that the karst is very active today as the reasoning. However, a section on the coast cut through a large (c. $200 \mathrm{~m}$ diameter) sediment-infilled doline revealed a continuous sequence of glacial, freshwater and marine fossiliferous deposits beginning from before the Sangamonian and extending into the early Wisconsinan (Brookes et al., 1982).

A difficulty that must be addressed in explaining intact or partly-intact pre-LGM schlottenkarren and other karst features is how features developed on such soft rocks survived the intense glaciation experienced in the region. One important explanatory factor is that there can be considerable denudation from ice scouring without complete destruction of karst surfaces. Observed modern doline depths of $>10 \mathrm{~m}$ added to the similar depths of some associated shafts show that in some places subject to glacial scour removal of up to $20 \mathrm{~m}$ or more of rock would have been needed to completely level many karst surfaces, so, many areas could have experienced only partial truncation of pre-existing morphologies (Figs. 11 \& 12). This appears to be what happened at The Honeycombs, and it also resolves the apparent paradox that the appearance of some newly-exposed surfaces implied that these very soft rocks had suffered as little as one metre of glacial scouring. In other areas (such as the vicinity of Wisqoq Cave) where there was less denudation and schlottenkarren survived more or less intact, burial under static ice explains preservation of the karst surfaces. The presence of widespread static ice in Nova Scotia has been proven by survival of unconsolidated prePleistocene saprolites developed on granitoid rocks (O’Beirne-Ryan \& Zentilli, 2003, 2006).

Formation of schlottenkarren during deglaciation might be an alternative explanation. The most rapid 
rates of cave development anywhere probably occur at glacier margins during the melting stages (Ford, 1987) and Baechler \& Boehner (2014 p. 711) suggest the possibility of an origin at local ice margins to explain three anomalous sites in Cape Breton where bare, highly-karstified gypsum outcrops occur immediately adjacent to deeply till-mantled or denuded karst surfaces. However, whilst paraglacial processes could have been involved in these particular cases, the common occurrence of schlottenkarren in unglaciated regions elsewhere in the world (see above) rules this out as a universal or even general process.

A more precise chronology than 'pre-LGM' is difficult to propose at this time. Considered in isolation, the features observed in Wisqoq Cave and The Honeycombs can be interpreted as having being formed during the Sangamon interglaciation or a Wisconsinan interstadial. However the dating evidence from palaeokarst sediments elsewhere in the region points to a Wisconsinan age as the most likely for these two caves.

\section{DISCUSSION AND CONCLUSIONS}

Schlottenkarren develop on exposed gypsum surfaces where a sufficiently large hydraulic head above a water-table is combined with essentially unimpeded egress of water flow into underlying phreatic cavities. Those occurring in the study area are exhumed pre-Last Glacial Maximum (LGM) features which have survived from the Wisconsinian intact or partly-intact. This implies that the degree of glacial scouring and denudation of the gypsum terrains in this region is highly variable (Figs. $11 \& 12$ ), and the extent of post-glacial karstification has often been overemphasized. It is probable that many or most karst landforms and associated caves in Nova Scotia and elsewhere in Atlantic Canada have a significant pre-LGM component in their development.

It can be inferred that the nature of the landscape at the end of the Sangamon Interglacial was similar to that of today, comprising a complex mixture of both active and inert buried and exposed karst. During the following Wisconsinan ice age some areas under static ice experienced little or no scouring, thus preserving pre-existing morphologies and infill sediments.

The survival of early karsts, protected beneath thick impermeable glacial deposits, is potentially valuable for studies of the Quaternary, an epoch which is littleunderstood in the region. The extent of denudation can indicate the distribution of moving versus static ice. So far, although no known sites in the Maritimes match the continuity and clarity of the Newfoundland Codroy locality, sedimentary records preserved in deep sediment-infilled sinkholes, vertical shafts and underlying cavities are known to contain stratified Sangamonian and Wisconsinan chronological sequences. These sediments contain well-preserved palynological and macrofossil evidence of the Late Pleistocene in this part of Canada, and it is likely that sites preserving more detailed and comprehensive chronological sequences exist. Importantly, the presence of Mesozoic deposits associated with gypsum karst shows that earlier sediments can also survive, and it is therefore quite likely that evidence of the Illinoian or pre-Illinoian glacial and interglacial episodes which are almost unknown in this geographical region has survived.

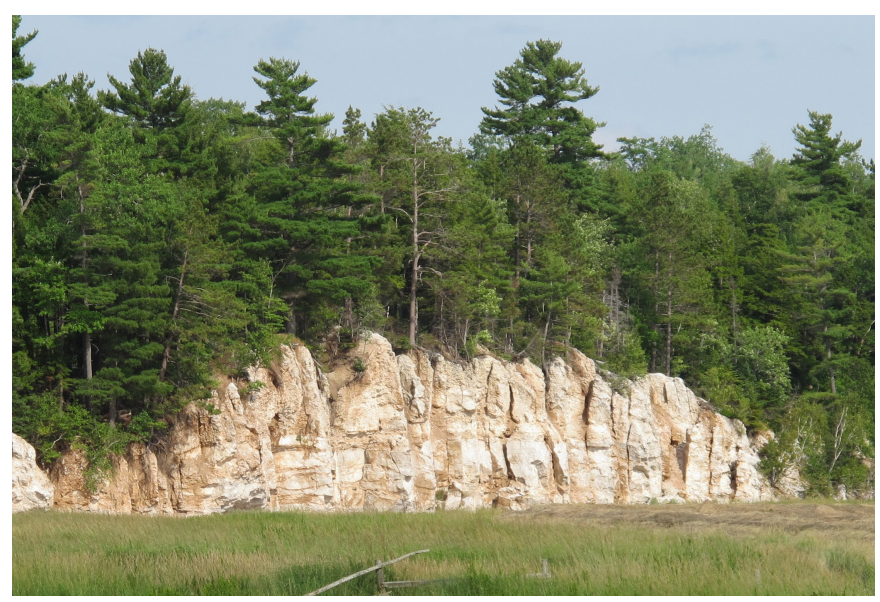

Fig. 11. Partly-denuded schlottenkarren karst surface exposed in riverside cliffs, St. Croix River, Hants County, Nova Scotia. At this point glacial action appears to have removed only a few meters of rock, leaving pre-glacial surface morphologies largely intact. Several (sub)vertical shafts are exposed in the cliff face (Photo: author).

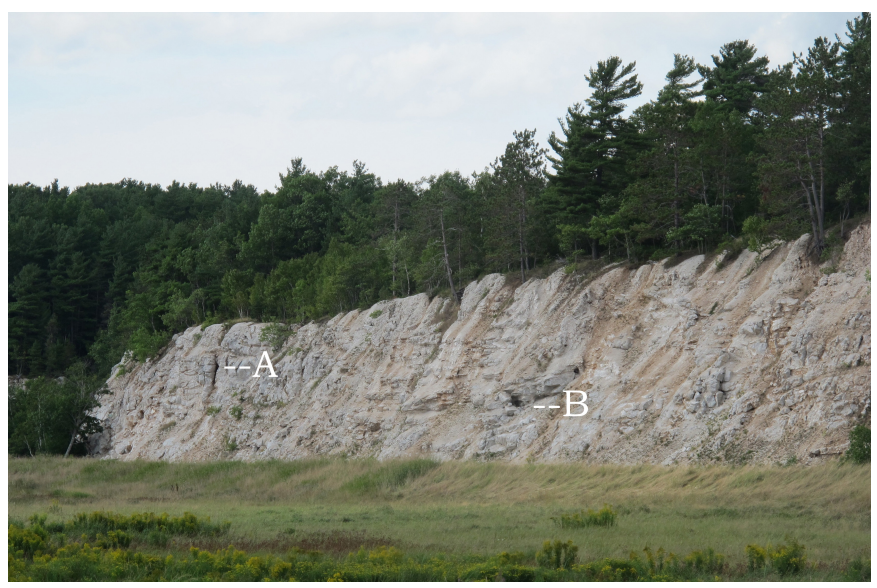

Fig. 12. Highly-denuded karst surface exposed in riverside cliffs, St. Croix River. Here the pre-glacial karst surface has almost entirely been erased, but sub-surface features survive. The remnant of a vertical schlottenkarren shaft is visible at ' $A$ ', and a small inactive and sediment-choked phreatic cave (St. Croix River Cave) can also be seen (B) (Photo: author).

Finally, some of the ideas offered here might also be applicable to the dissolution pipes in calcareous deposits that have been reported from coastal areas in tropical or subtropical climates in many areas in the world (De Waele et al., 2011). These display a number of similarities with gypsum schlottenkarren. They are composed of almost perfect cylindrical vertical holes with no apparent relationship with dip of strata or fractures, and are found near coastal cliffs. Examples in Tunisia of closely-packed groups resembling 'pinnacle karst' appear to be remnants whose upper parts have been removed by erosion (De Waele et al., 2011, p. 465 \& Fig. 1C).

\section{ACKNOWLEDGEMENTS}

Wisqoq Cave mapping: David Sawatzky and Doug Munroe, assisted by Jonathan Guy, Philippe Pautel and Matt Smith. Special thanks are due to Matt who 
discovered, reported and named Wisqoq Cave, and to Dr. F Baechler for an informative discussion about gypsum karst in Cape Breton. Firouz Vladi and two anonymous reviewers kindly read and critiqued earlier versions of the submitted MS and made many valuable suggestions that significantly improved it.

\section{REFERENCES}

Adams G.C., 1991 - Gypsum and anhydrite resources in Nova Scotia. Economic Geology Series 91-1, Nova Scotia Department of Natural Resources, Halifax, 193 p.

Baechler F. \& Boehner R., 2014 - Karst geology and hydrogeology of Cape Breton Island, Nova Scotia: an overview. Canadian Journal of Earth Sciences, 51 (7): 701-714. https://doi.org/10.1139/cjes-2013-0157

Bell W.A., 1929 - The Horton-Windsor District, Nova Scotia. Geological Survey of Canada, Memoir 155, Ottawa, King's Printer, 268 p.

Biese W., 1931 - Über Höhlenbildung, 1. Teil, Entstehung der Gipshöhlen am südlichen Harzrand und am Kyffhäuser. Abhandl. d. Preussichen Geolischen Landesanstalt, Neue Folge, 137, Berlin, 71 p.

Brookes I.A., McAndrews J.H. \& von Bitter P.H., 1982 - Quaternary interglacial and associated deposits in southwest Newfoundland. Canadian Journal of Earth Sciences, 19: 410-423. https://doi.org/10.1139/e82-033

Cole L.H., 1930 - The gypsum industry of Canada. Canada Department of Mines, Mines Branch, Ottawa, $164 \mathrm{p}$.

De Waele J., Lauritzen S.E. \& Parise M., 2011 - On the formation of dissolution pipes in Quaternary coastal calcareous arenites in Mediterranean settings. Earth Surface Processes and Landforms, 36 (2): 143-157. https://doi.org/10.1002/esp.2022

Falcon-Lang H.J., Fensome R.A., Gibling M.R., Malcolm J., Fletcher K.R. \& Holleman M., 2007 - Karst-related outliers of the Cretaceous Chaswood Formation of Maritime Canada. Canadian Journal of Earth Sciences, 44 (5): 619-642. https://doi.org/10.1139/e06-119

Ford D.C., 1997 - Principal features of evaporite karst in Canada. Carbonates and Evaporites, 12 (1): 15-23. https://doi.org/10.1007/BF03175798

Ford D.C., 1987 - Effects of glaciations and permafrost upon the development of karst in Canada. Earth Surface Processes and Landforms, 12: 507-522. https://doi.org/10.1002/esp.3290120508

Ford D.C. \& Williams P.W., 1989 - Karst geomorphology and hydrology. Chapman and Hall, London, $601 \mathrm{p}$. https://doi.org/10.1007/978-94-011-7778-8

Friedman G.M., 1997 - Solution-collapse breccias and palaeokarst resulting from dissolution of evaporite rocks, especially sulphates. Carbonates and Evaporites, 12: 53-63. https://doi.org/10.1007/BF03175802

Goldthwait J.W., 1924 - Physiography of Nova Scotia. Geological Survey of Canada, Memoir 140, Ottawa, King's Printer, 179 p.

Goodman N.R., 1952 - Gypsum and anhydrite in Nova Scotia. Nova Scotia Department of Mines, Memoir No. 1, Halifax, N.S., 75 p.

Grantham R.G. \& Kozera-Gillis K.A., 1992 - The East Milford Mastodon dig: Progress report to May 1, 1992. Unpublished M.Sc., Nova Scotia Museum, Halifax, N.S., 38 p.

Gripp K., 1912 - Über den Gipsberg in Segeberg und die in ihm vorhandene Höhle. Hamburg Wisschaftliche Anstalten, 30: 35-51.

Harrington C.R., 1990 - Vertebrates of the Last Interglaciation in Canada: a review, with new data. Géographie physique et Quaternaire, 44 (3): 375-387. https://doi.org/10.7202/032837ar
Holman J.A. \& Clouthier S.G., 1995 - Pleistocene herpetofauna remains from East Milford mastodon site (ca. 70,000-80,000 BP), Halifax County, Nova Scotia. Canadian Journal of Earth Sciences, 32: 210-215. https://doi.org/10.1139/e95-017

Hughes O.L., 1957 - Surficial geology of subenacadie map-area, Nova Scotia. Geological Survey of Canada, Paper 56-3, Ottawa, 10 p.

Jackson C.T. \& F. Alger F., 1829 - A Description of the mineralogy and geology of a part of Nova Scotia. American Journal of Science and Arts, 15: 132-160.

James A.N., Cooper A.H. \& Holliday D.W., 1981 - Solution of gypsum cliff (Permian Middle Marl) by the River Ure at Ripon Parks, North Yorkshire. Proceedings of the Yorkshire Geological Society, 43 (4): 433-450. https://doi.org/10.1144/pygs.43.4.433

Kempe S., 1972 - Cave genesis in gypsum with particular reference to underwater conditions. Cave Science, 49: $1-6$.

Kempe S., Brandt A., Seeger M. \& Vladi F., 1975 "Facetten" and "Laugdecken", the typical morphological elements of caves developing in standing water. Annales de Spéléologie, 30 (4): 705-708.

Kempe S. \& Emeis K., 1979 - Geschichte einer Schlotte im Naturschutzgebiet Hainholz/Südharz. Heimatblätter für den südwestlichen Harzrand, 35: 63-74. https://www.karstwanderweg.de/publika/ heimatbl/35/63-74/index.htm

Klimchouk A.B. \& Aksem S.D., 2005 - Hydrochemistry and solution rates in gypsum karst: case study from the Western Ukraine. Environmental Geology, 48: 307-319. https://doi.org/10.1007/s00254-005-1277-3 Major M., 1966 - Spelunking. Atlantic Advocate, 57: 45-48. Martinez J.D. \& Boehner R.C., 1997 - Sinkholes in glacial drift underlain by gypsum in Nova Scotia, Canada. Carbonates and Evaporites, 12 (1): 84-90. https://doi.org/10.1007/BF03175806

Moseley M., 1996 - The gypsum karsts and caves of the Canadian Maritimes. Cave and Karst Science, 23 (1): 5-16.

Moseley C.M., 1988a - The solution caves of Nova Scotia: an update. The Canadian Caver, 20: 38-41.

Moseley C.M., 1988b - Caves of Nova Scotia: an annotated list. The Canadian Caver, 20: 42-44.

Moseley M., 1976 - Caves of the Atlantic Region. In: Thompson P. (Ed.), Cave exploration in Canada: A Special Issue of the Canadian Caver Magazine. The Canadian Caver Magazine, University of Alberta, Edmonton, 8-18.

Moseley M., 1974 - The Honeycombs, Hants Co. N.S. Newsletter No. 3, Nova Scotia Speleological Society. Nova Scotia Museum, Halifax, p. 6-9.

Moseley M., Smith M., Broders H. \& Burns L., 2013 Ecology of Wisqoq Cave, a raccoon-inhabited cave in Nova Scotia. Speleobiology Notes, 5: 66-73.

O’Beirne-Ryan A.M. \& Zentilli M., 2006 - Weathering of Devonian monzogranites as recorded in the geochemistry of saprolites from the South Mountain Batholith, Nova Scotia, Canada. Atlantic Geology, 42 (2-3): 153-160. https://doi.org/10.4138/2785

O’Beirne-Ryan A.M. \& Zentilli M. 2003. Paleoweathered surfaces on granitoids of Southern Nova Scotia: Paleoenvironmental implications of saprolites. Canadian Journal of Earth Sciences, 40 (6): 805-817.

https://doi.org/10.1139/e03-016

Pfeiffer D. \& J. Hahn J., 1972 - Karst of Germany. In: Herak M. \& Stringfield V.T. (Eds.) Karst: Important karst regions of the Northern Hemisphere. Elsevier, Amsterdam, p. 189-223. 
Roland A.E., 1982 - Geological background and physiography of Nova Scotia. Nova Scotia Institute of Science, Halifax. 311 p.

Stea R.R., Seaman A.A., Pronk T., Parkhill M.A., Allard S. \& Utting D., 2011 - The Appalachian Glacier Complex in Maritime Canada. In: Ehlers J., Gibbard P.L. \& Hughes P.D. (Eds.), Quaternary glaciations - Extent and chronology. Elsevier, Amsterdam, p. 631-660. ttps://doi.org/10.1016/B978-0-444-53447-7.00048-9

Stenson R.E., 1990 - The morphometry and spatial distribution of special depressions in gypsum, with examples from Nova Scotia, Newfoundland and Manitoba. Unpublished M.Sc. thesis, McMaster University, Canada, 134 p.
Stevenson I.M., 1959 - Shubenacadie and Kennetcook Map-Areas, Colchester, Hants and Halifax Counties, Nova Scotia. Geological Survey of Canada Memoir 302, Canada Department of Mines and Technical Surveys. The Queen's Printer, Ottawa, $88+$ vii p.

Sweet G. A., 1978. - The morphology and hydrogeology of gypsum karst, Codroy, Newfoundland. Research Paper, Department of Geology, McMaster University, 140 p.

Vladi F., 1979 - Die Nashornfunde zu Düna (NSG Hainholz) vom Jahre1751 -und ihre Bedeutung für "die physische Geschichte unseres Planeten". Heimatblätter für den südwestlichen Harzrand, 35: 39-54.

Williams M.Y., 1914 - Arisaig-Antigonish District, N.S. Memoir 60, Geological Survey of Canada, Ottawa, 173 p. 